\title{
Acceptability of Students With Disabilities in Higher Education: Towards Inclusive Education at Universitas Ahmad Dahlan, Indonesia
}

\author{
Muya Barida ${ }^{1}$, Nurul Hidayati Rofiah², Meita Fitrianawati ${ }^{3}$
}

\begin{tabular}{l} 
ARTICLE INFO \\
\hline Article History: \\
Received 07.07.2019 \\
Received in revised form \\
26.02 .2020 \\
Accepted \\
Available online 01.03 .2020$.
\end{tabular}

INTRODUCTION

Persons with disabilities those who experience disturbances, difficulties, or obstacles in carrying out specific activities/functions, so they need special tools, environmental modifications, or specific alternative techniques to be able to learn and participate fully and effectively in social life. Barida and Widyastuti (2019) states that children with special needs are children with disabilities in the development of life due to disruption (mental, intellectual, emotional, social, physical) in the socio-social, career, and academic fields, so they need special services and are different from children in general. Among them are those who experi.ence barriers to visual function (visually impaired), impediments to hearing and speech (hearing impaired) functions, barriers to physical-motor function, autism spectrum disorders, and others.

Persons with disabilities are those who experience disturbances, difficulties, or obstacles in carrying out specific activities/functions, so they need special tools, environmental modifications, or specific alternative techniques to be able to learn and participate fully and effectively in social life. Among them are those who experience barriers to visually impaired, impediments to hearing and speech (hearing impaired) functions, barriers to physical-motor function, autism spectrum disorders, and others. Inclusive environment makes the communication skills of autistic children can be increased (Ismiarti, Yusuf, and Rohmad, 2019).

Fulfillment of the rights of persons with disabilities in the context of education must at least pay attention to four indicators, including 1) Indicators of availability. 2) Accessibility indicators. 3) Indicators can be accepted (acceptability). 4) Indicators can be adapted (adaptability). Some of these indicators confirm that related to education for students with disabilities, not only are the programs and facilities available, but they can also be accessed quickly and even with the principle of non-discrimination. Based on the indicators

${ }^{1}$ Corresponding e-mail: muya.barida@bk.uad.ac.id https://orcid.org/0000-0002-2986-5177, Ahmad Dahlan University

${ }^{2}$ https://orcid.org/0000-0003-0092-8709, Ahmad Dahlan University

${ }^{3}$ https://orcid.org/0000-0002-3748-3718, Ahmad Dahlan University 
of acceptability, education should be accepted by inclusive students, and vice versa, the education community, in general, can fully accept inclusive students. Yusuf (2016) emphasized that the phenomenon of inclusive education in Indonesia can be traced through two things 1) Regulations that describe policies, and 2) Field research that illustrates inclusive education infield practice.

Persons with disabilities not only have the same rights to obtain an education as other citizens, as stated in the 1945 Constitution, but also have the right to obtain a quality education. In-Law Number 20 the Year 2003 concerning the National Education System, it is stated that every citizen (without exception) has the right to obtain quality education (article 5 paragraph 1). However, the consequences of this law require readiness from education implementers, namely schools and colleges.

Barriers experienced by individuals with disabilities cause them to need special education services. This is confirmed and guaranteed in Law Number 20 Article 5 Paragraph 2, which states that citizens who have physical, emotional, mental, intellectual, or social disabilities are entitled to special education. In the explanation of Law No. 20/2003, it is stated that special education for persons with disabilities can be carried out in special education institutions and public education institutions (inclusive education setting).

Currently, educational opportunities for people with disabilities have been wide open. This is evidence of the concern and commitment of the government and the people of Indonesia to help people with disabilities fulfill their right to education for a better life. In 2009, the government, through the ministry of national education, specifically issued a ministerial regulation on inclusive education for persons with disabilities and individual intelligent students and unique talents (Permendiknas Number 70 of 2009). This indicates that the government wants to encourage and facilitate persons with disabilities to take education in public education institutions (inclusively) to expand educational opportunities in primary and secondary education units. From the data entered into the Directorate of Learning of Kemenristekdikti, there were 401 disabled students from 152 tertiary institutions who had reported. They come from various types of obstacles (visually impaired, deaf, deaf, and others), and they are scattered in various study programs (Nurlailiyah, 2015).

Basically, all majors or study programs in Higher Education must be open to the presence of students with disabilities. Determination of requirements for prospective students should be more focused on the academic ability of prospective students, not because of the disability aspects. Thus, disability should not be used as a measure of the unacceptability of prospective students entering specific study programs because it can be considered contrary to the 1945 Constitution, which among others, states that every citizen has the right to get a quality education. Likewise, in the world convention on the rights of persons with disabilities, it has been ratified into Law Number 19 of 2011 concerning the Ratification of the Convention on the Rights of Persons with Disabilities. During this time, the data distribution of students with special needs has not been reported valid. There are children with special needs with a variety of types and characteristics.

The phenomenon of children with special needs each year shows or increases in number (Sopiatun, 2013). The increasing number of children with special needs every year is not in line with inclusive education services. The implementation of inclusive education is not all in accordance with the guidelines for implementation both in terms of the conditions of students, teachers, infrastructure, parents' support, and support from the government (Praptiningrum, 2012).

Universitas Ahmad Dahlan promotes inclusive education, accepting students with various backgrounds, including students with special needs. This study aims to explore more deeply the acceptability of persons with disabilities in tertiary institutions.

\section{Situation of the Problem}

Individuals with disabilities need specific ways, tools, and environmental conditions so that they can carry out learning activities and other activities efficiently and safely, for example riding a motorcycle, walking, eating, playing. In accessing information, the blind need to be facilitated to use equipment that emphasizes the auditive and physical functions. Deaf people need visual media so they can access information efficiently and effectively. The physical impairment requires modification of tools and physical environment so that they can carry out activities and mobility quickly and safely. Autism requires a special 
approach to communicate and interact with others effectively. Likewise, other types of disabilities require different modifications.

\section{Aim of the Study}

This study aims to explore and map the level of acceptability (level of acceptance) of students with special needs in higher education

\section{METHOD}

This research was conducted using a type of field research with a qualitative approach. This research is a case study at Universitas Ahmad Dahlan. The consideration in choosing a research location is because Universitas Ahmad Dahlan promotes inclusive education, accepting students with various backgrounds, including students with special needs. In this study, researchers present qualitative descriptive research results. The collected data in the form of narration, words, images, stories, and even data in the form of numbers becomes a conclusion in the form of a description.

\section{Material}

Data sources that the authors use to obtain valid and relevant data in this study are in the form of interviews from various sources and supported by written data. Interview data obtained from several speakers, including 1). Head of an admission bureau, 2) Chancellor in the academic field, 3) study program head, 4) UAD students. The written data sources used include books, scientific journals, relevant research results, school documents, as well as personal documents, and other official documents relating to the way of learning for disabled students. Written data or sources are used to support and strengthen the data obtained from the interview data search results.

\section{Data Analyses}

Data analysis in this study uses qualitative analysis. Each diary produced in the collection of data derived from interviews, observations and analysis of documents is then selected, analyzed, and summarized into a narrative description. Data that has been collected if it is deemed to be lacking or incomplete can be searched again immediately from relevant sources. Estuary of all qualitative data analysis activities lies in the depiction or narrative of what has been successfully investigated.

\section{FINDINGS}

In 2017 the Ministry of Research, Technology, and Higher Education issued Permenristekdikti Number 46 of 2017 concerning Special Education and Special Service Education in Higher Education. The presence of Permenristekdikti number 46/2017 is significant for the world of higher education because now, more and more citizens with disabilities are studying in tertiary institutions. From the data entered into the Directorate of Learning of Kemenristekdikti, there were 401 disabled students from 152 tertiary institutions who had reported. They come from various types of obstacles (visually impaired, deaf, deaf, and others), and they are scattered in various study programs (Septiana and Efendi, 2019).

Various types of students with special needs received at UAD include those who have physical and learning difficulties. Some of them have a visual impairment, hearing impairment, physical obstacles, learning difficulties. Physical barriers are characterized by a limited individual ability to function physically as expected (Hakeem, 2015). Physical barriers are conditions of disability or health disorders that require adaptation (Disabled World, 2019). It can be seen that people with physical disabilities often use hearing aids, hearing aids, or mobility aids such as crutches, wheelchairs, and artificial limbs for mobility.

Physical barriers can be categorized according to weaknesses in specific organs. Physical barriers are defined as any condition that results in sensory or motor disturbances, such as vision or hearing impairment, loss of limbs, excessive pain or fatigue, uncontrolled seizures, difficulty breathing, and abnormal or limited movements, for periods of time that are continuous or not limited (Hinman, 2015). Efendi (2006) said that physical barriers could be divided into blind, deaf, deaf, and deaf. Children with physical disabilities, despite experiencing physical barriers but are often found in competitive activities. As is well known by the public, that Governments around the world support the existence of world sports championship or Paralympic. The study found that an active child who is sporty, who uses a wheelchair, is 
Barida,M., Rofiah,N.H. \& Fitrianawati,M. (2020). Acceptability of students with disabilities in higher education: Towards inclusive education at Universitas Ahmad Dahlan Indonesia. International Journal of Educational Research Review,5(2),151-158

considered more competent than a child who can be physically active and sporty (Gebhradt, Mora, and Schwab, 2016).

Table 1.

The List of Students with Disabilities for the Academic Year Of 2018/2019

\begin{tabular}{lllcc}
\hline No & Disabilities & Category & Assessment (Yes/No) & Total \\
\hline 1. & Intellectual disabilities & Mild & Yes & 3 \\
2. & Physical Disabilities & $\begin{array}{l}\text { Polio, visual } \\
\text { impairment, deaf }\end{array}$ & Yes & 6 \\
3. & Superior & Gifted & Yes & 2 \\
4. & Slow Learning & Borderline & Yes & 9 \\
5. & Specific learning & Dyslexia, dysgraphia & No & 3 \\
& Disabilities & & & \\
\hline
\end{tabular}

\section{RESULT, DISCUSSION, AND SUGGESTIONS}

Less than one percent of people with disabilities have $\mathrm{S} 1$ degrees because of limited access to education for people with disabilities (Lembaga Bahtsul Masail PBNU, P3M, and PSLD UB, 2018). In Indonesia, the education model for people with disabilities is still segregative by providing exceptional education through special schools or boarding schools. Such a model separates people with disabilities from non-disabled people in different environments so that after finishing the study period, persons with disabilities are still not ready to blend in with the environment. Access to tertiary education is also difficult for persons with disabilities to penetrate because of the requirement to enter tertiary institutions, which reads "tidak cacat tubuh." That the meaning is " no disability."

Universitas Ahmad Dahlan accepts new students from among children who do not have special needs and children with special needs. This is because Universitas Ahmad Dahlan considers that persons with disabilities not only have the same rights to obtain an education as other citizens, as stated in the 1945 Constitution, but also have the right to obtain a quality education. In-Law Number 20 the Year 2003 concerning the National Education System, it is stated that every citizen (without exception) has the right to obtain quality education (article 5 paragraph 1). In accepting new students, there is no specific path that is devoted to students with special needs. The flow of admission of new students must pass the selection of several written examinations. This is in line with the mechanism and criteria for admission of new students with disabilities, as stipulated in Permenristekdikti number 126 of 2016 concerning Admissions of Undergraduate Students at State Universities. In the regulation, the closest thing to fulfilling the rights of persons with disabilities in participating in the selection of new students at state universities is Article 3 point (a), namely that the pattern of admission of new students is carried out with the principle of justice, which does not distinguish between religion, ethnicity, race, gender, age, social position, physical condition, and level of economic ability of prospective students. These rules still pay attention to the potential and academic achievement of prospective students and the specificity of the Study Program in the Higher Education concerned. First, it starts with a consultation to the study program then continues to fill in an online form and completeness of the file. The completeness documents consist of the last diploma and value transcript. After that, pay the registration fee (PMB UAD, 2019).

Several components exist in the school to be the deciding factor in the acceptance of higher education for students with special needs who wish to enroll in the school. Some of these components include, from campus.

First, policies that support people with disabilities - related to the support of policies that favor children with special needs in accessing higher education. The policies issued by universities must be more sensitive to disabilities (Sholeh, 2015). The policies include facilities and infrastructure. Provision of facilities that support the teaching-learning process for persons with disabilities. Support infrastructure that is accessible and disabled-friendly. Higher education leaders facilitate the formation of an inclusive culture on campus and increase the competence of lecturers and education personnel in providing services to Students with Special Needs. Higher education facilitates learning and assessment according to the needs of Students with Special Needs without reducing the quality of learning outcomes. Three strategies that need to be done 
to create inclusive education are inclusive / differetiated assessment, motivation and goal strategies, inclusive pedagogy (Awang-Hashim, Kaur, and Valdez, 2019).

One of the efforts has been made by establishing the Ahmad Dahlan disability study and service center in 2018. The disability study and service center aims to plan development and assessment activities on inclusive education. It also aims to improve the quality of education services for people with disabilities, especially in higher education. It also provides an environment, facilities, and service systems that suit the needs of people with disabilities, so that they can learn optimally. With the existence of a study center, there is hope to build the atmosphere of UAD to become a friendly and accessible campus for persons with disabilities and realize the equal right to education as the general public. It is creating a campus environment that is more sensitive and concerned about equal rights.

Second, accessibility of facilities and infrastructure. Persons with special needs should be able to take advantage of all public facilities, both in the home, school, work/office environment, transportation facilities and infrastructure, pedestrian paths/sidewalks, toilets, and government buildings. The needs that support the achievement of easy access for people with special needs vary so that it requires physical development so that an environment that can be easily accessed by everyone (accessible) can be realized. The ease of mobility in question is related to physical development, for example, construction of ramps for wheelchair users, installation of a guide path for the visually impaired, making pedestrian paths, and toilets that are easily accessible by everyone. Campus as an education service provider needs to provide accessibility both for daily activities and for the convenience of evacuation in the event of a disaster. Universitas Ahmad Dahlan, several public facilities have been designed according to the needs of people with disabilities, for example, in mosques, toilets, elevators, and study rooms. High-quality experience and services provided to students with physical disabilities are needed so that they can learn and achieve optimal academic performance (Gelbar et al., 2015).
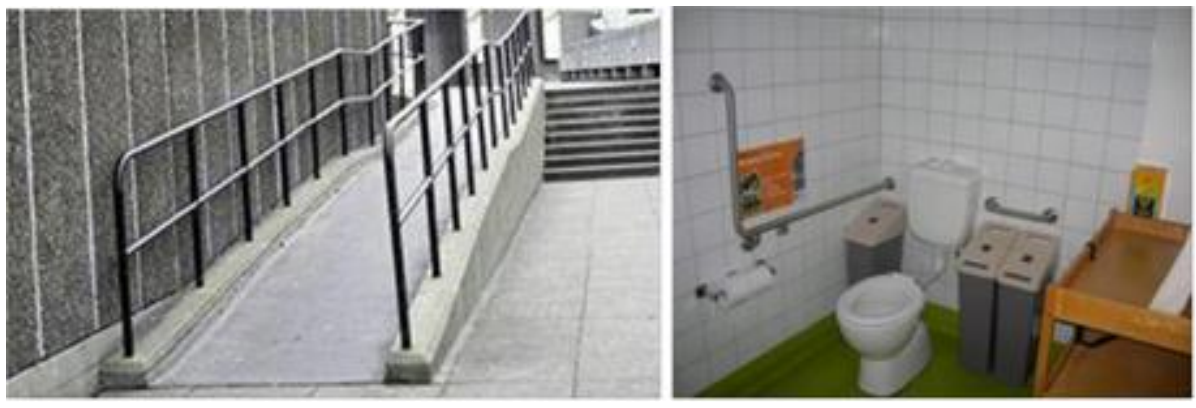

Figure 1. Ramp and Toilet in Universitas Ahmad Dahlan

Students with special needs should be able to access the education funding. In terms of education funding, it is emphasized that the Government is obliged to organize and facilitate education for persons with disabilities through inclusive education and special education. The government is also "obliged to provide tuition fees for children with disabilities" At present, the access of persons with disabilities to tertiary institutions is highly dependent on the economic conditions of families where most come from families with economic limitations. High higher education costs become unaffordable. Persons with disabilities require a higher cost of living because they need tools and require periodic access to medical, social, or psychological interventions. There are scholarships explicitly given to underprivileged (poor) students at Universitas Ahmad Dahlan. Besides, there is also a scholarship from the government through Ristekdikti, which is specifically for people with disabilities.

The third component is the educator. The response to change is also addressed differently from the educator component. Initially, some educators had a chance to respond to disagreement over campuses that accept students with special needs. Educator capacity related to competence in serving students with special needs is still minimal. The perception of some educators in persons with disabilities doubts their academic abilities due to inherent physical limitations (Steven and Sawitri, 2016). The mismatch of community treatment, among others, is shown by ignorance, neglect, fear that alienates individuals who have physical 
barriers (Hakeem, 2015). Thornicroft, Rose and Kassam (2017) revealed, negative attitudes and behaviors of others have adverse effects on children and adults with disabilities, which lead to negative consequences such as low self-esteem and reduced participation. This is minimized by technical guidance related to special education. The lecturers become more open, wanting to learn more about how to accommodate and modify learning. The condition of the change in the mindset of educators from refusing and following the training was precisely touched and supporting the acceptance of students with special needs.

Knowledge and insight about inclusive education are the main determinants of the campus environment to accept, reject, or accept but allow unhealthy processes to occur on campus, including the existence of bullying (Kurniawan and Rofiah, 2018). Factors of insight and knowledge become the main factors that appear in changes in the perception of lecturers before getting training on inclusive education and after getting training. Before receiving training on inclusive education, some teachers insisted they would not accept people with disabilities. However, after some of the lecturers who refused to receive enough knowledge and insight, the teacher instead became the intermediary for a scientific entry related to inclusive education services. Also, there is a sense of empathy that arises from some teachers after getting knowledge about inclusive education (Dulisanti, 2015). The positive attitude of teachers can generate acceptance, while the negative attitudes of teachers can lead to rejection to inclusive education (Saputi, 2018). One of the factors influencing this attitude is the view of children with special needs, type of teacher, grade level, teacher beliefs, socio-political views, teacher empathy, and gender (Setiyaningsih, 2015).

Several study programs in the faculty of education and education have inclusive education courses. This is to prepare prospective teachers to have competencies which include the delivery of special education concepts related to the philosophical foundation that underlies the importance of inclusive education, training special skills complemented by the development of learning design instruments, media design, and media creation practices, practice of providing compensatory services, ability managerial education and mentoring of children with special needs in an inclusive school environment. It also changes their negative perceptions of children with special needs.

Some lecturers recognize that their scientific limitations related to special education bring consequences to the inappropriate assessment of inclusion students. Some lecturers who became the pioneers of the training on inclusive education continued to be the introduction of knowledge to other teachers related to the implementation of inclusive education in Universitas Ahmad Dahlan. The condition is as the result of Sunanto's research (2009), which states that changes in acceptability behavior about inclusive campuses are influenced by knowledge and knowledge about inclusive campuses and students with special needs obtained by someone. Good acceptance begins from experience faced by the educational community component at Universitas Ahmad Dahlan in the implementation of inclusive higher education. Elisa and Wrastari (2013) said that one factor that increases student acceptance is the experience factor, which consists of teaching experiences of student with disabilities and experience of contact with student with disabilities.

The acceptability of student with disabilities in higher education is entirely good after going through various processes. Universities try to accept children with special needs even though they still lack in some services. It can be seen from the policy of admission of new students, the competence of educators about special education, which is still minimal, infrastructure, and support from various parties. This study found three main components that play a role in the acceptance of persons with disabilities, namely campus disability-friendly policies, accessible facilities, and educators. The higher education environment that accepts people with disabilities will increasingly realize the need for equal opportunities in all fields so that students with disabilities have meaningful and productive academic and social lives. It is hoped that lecturers need to receive classroom management program training, so that they are able to perform better on problem solving, preventing misbehaviors, classroom management, and applying discipline (Aydin and Karabay, 2020).

\section{REFERENCES}

Awang-Hashim, R., Kaur, A., and Valdez, N.Pd. (2019). Strategizing inclusivity in teaching diverse learners in higher education. Malaysian Journal of Learning and Instruction (MJLI), 16(1), 105-128.

Aydin, D.G., and Karabay, Ş.O. (2020). Improvement of classroom management skills of teachers leads to creating positive classroom climate. International Journal of Educational Research Review, 5(1), 10-25. 
Barida, M. and Widyastuti, D.A. (2019). Acceptance and commitment therapy (act) to improve educators self-acceptance of children with special needs. Konseli Jurnal Bimbingan dan Konseling, 6(2), 117-124.

Disabled World. (2019). Physical and mobility impairments: Information and news, (online), (https://www.disabled-world.com/disability/types/mobility/), 20 January 2019.

Dulisanti, R. (2015). Social Acceptance in the inclusive education process case study in the inclusive education process at SMK Negeri 2 Malang (Penerimaan Sosial Dalam Proses Pendidikan Inklusif Studi Kasus Pada Proses Pendidikan Inklusif di SMK Negeri 2 Malang). Indonesian Journal of Disability (IJDS), 2(1), 52-60.

Efendi, M. (2006). Introduction to the psychopedagogic of children with disabilities (Pengantar Psikopedagogik Anak Berkelainan). Jakarta: Bumi Aksara.

Elisa, S and Wrastari, AT. (2013). Teachers' attitudes towards inclusive education viewed from the forming factors of attitude. Jurnal Psikologi Perkembangan dan Pendidikan, 2(1).

Gebhradt, Mora, and Schwab. (2016). Physical disability, stigma, and physical. Journal Of Special Education And Rehabilitation, 17(1), $101-117$.

Gelbar, Madaus, Lombardi, Faggella-Luby, and Dukes. (2015). College students with physical disabilities: Common on campus, uncommon in the literature. Physical Disabilities: Education and Related Services, $34(2), 14-31$.

Hakeem, K.A. (2015). People with physical disabilities and their working life: A case study about finnish people with physical disabilities, Tesis. Finlandia: Diaconia University

Hinman, Peterson, and Gibbs. (2015). Prevalence of physical disability and accommodation needs among students in physical therapy education programs. Journal of Postsecondary Education and Disability, 28(3), 309-328.

Ismiarti,R.D., Yusuf,M. and Rohmad,Z. (2019). Communication abilities of autistic children in social interaction. International Journal of Educational Research Review, 4(2),172-177.

Kurniawan, Muhammad Ragil dan Nurul Hidayati Rofiah. (2018). Acceptability of children with special needs in inclusive elementary school, 12(4), 589-596.

Lembaga Bahtsul Masail PBNU, Perhimpunan Pengembangan Pesantren Dan Masyarakat (P3M), Dan Pusat Studi Dan Layanan Disabilitas (PSLD) Unibraw. (2018). Fiqih Penguatan Penyandang Disabilitas. Jakarta: Lembaga Bahtsul Masail PBNU

Nurlailiyah, Aris. (2015). Kritik Tafsir Ayat-Ayat Pendidikan Terhadap Pendidikan Segregasi, Pendidikan Inklusif, Dan Pendidikan Integrasi (Studi Pendidikan Di Perguruan Tinggi Yogyakarta) An-Nûr. Jurnal Studi Islam, 7(2), 147-166.

PMB UAD (2019). Booklet Penerimaan Mahasiswa baru 2020. http://pmb.uad.ac.id

Praptiningrum (2010). The phenomenon of providing inclusive education for children with special needs. Jurnal Pendidikan Khusus, 7(2).

Saputi, V. (2018). School Acceptance Toward Students With Special Need (Case Study In SMP Taman Dewasa Ibu Pawiyatan Yogyakarta). Jurnal Widia Ortodidaktika, 7(6), 644-660.

Setianingsih, E. S. (2018). Teacher acceptance and attitudes towards the existence of children with special needs in school. Empati: Jurnal Bimbingan dan Konseling, 5(1), 34-46.

Sholeh, A. (2015). Islam dan Penyandang Disabilitas: Telaah Hak Aksesibilitas Penyandang Disabilitas Dalam Sistem Pendidikan Di Indonesia. PALASTREN, 8(2), 293-319

Sopiatun (2013). Development of teaching materials for children with special needs for inclusive education in early childhood education program Universitas Tadulako. Tri Sentra Jurnal Ilmu Pendidikan. 
Barida,M., Rofiah,N.H. \& Fitrianawati,M. (2020). Acceptability of students with disabilities in higher education: Towards inclusive education at Universitas Ahmad Dahlan Indonesia. International Journal of Educational Research Review,5(2),151-158

Steven, Christofan Dorry dan Dian Ratna Sawitri. (2016). Bersyukur Di Tengah Sedih Dan Senangku: (Studi Kualitatif Subjective Well-Being Pada Mahasiswa Tunanetra). Jurnal Empati, 5(3), 439-442

Sunanto, J. (2009). Inclusion index in learning in classes that are ABK in Primary schools. JASSI_anakku, 8(2), 78-84.

Thornicroft, G., Rose, D. \& Kassam, A. (2007). Discrimination in health care against people with mental 1llness. International Review of Psychiatry (Abingdon, England), (19), 113-122.

Yusuf, M. (2016). Reflections on the implementation of inclusive education in Indonesia. Jurnal Difabel, $3(3), 67-70$. 